\title{
DEVELOPMENT OF PUBLIC SERVICES THROUGH THE IMPLEMENTATION OF EUROPEAN SELF-GOVERNMENT STANDARDS IN UKRAINE
}

\author{
ARANKA IGNASIAK-SZULC, ${ }^{1}$ SVITLANA KUCHERENKO, ${ }^{2}$ \\ IRENEUSZ JAŹWIŃSKI, ${ }^{3}$ VIACHESLAV RIZNYK ${ }^{4}$ \\ ${ }^{1}$ Nicolaus Copernicus University in Toruń, Faculty of Economic Sciences and Management, POLAND \\ e-mail: aranka@umk.pl \\ ${ }^{2}$ Pereiaslav-Khmelnytskyi Hryhorii Skovoroda State Pedagogical University, Faculty of Finance and Humanities, UKRAINE \\ e-mail: ksvetau@i.ua \\ ${ }^{3}$ University of Szczecin, Faculty of Management and Economics of Services, POLAND \\ e-mail: ijazwinski@wp.pl \\ ${ }^{4}$ Pereiaslav-Khmelnytskyi Hryhorii Skovoroda State Pedagogical University, Faculty of Finance and Humanities, UKRAINE \\ e-mail: riznyk84@gmail.com
}

\author{
\begin{tabular}{l|l} 
RECEIVED & 6 November 2018
\end{tabular} \\ \begin{tabular}{l|l} 
ACCEPTED & 3 December 2018
\end{tabular} \\ JEL \\ CLASSIFICATION H70, L88, O20, R58
}

KEYWORDS European self-governments standards, public services, decentralization process, public governance

ABSTRACT As the experiences of the Central and Eastern European countries show, the reforms connected with decentralization were important in agendas of transformation. It must be also stressed that their implementation had not only political impact as formation and empowerment of new territorial authorities was targeted also on the provision of improved public services to citizens according to the European standards such principles of subsidiarity and self-government. The aim of the article is to present the recent attempts for decentralization and local reforms and their impacts in Ukraine in order to indicate achievements and the possibilities of strengthening public services through the implementation of European self-government and public governance standards. The paper explores the process connected with implementation of series of reforms conducted since 2014 in the researched field. It also proves that the acts recently adopted in Ukraine constitute legal basis not only for the distribution of powers between the authorities at various levels of territorial-administrative system, but they are aimed to improve the quality and efficiency of public services.

\section{Introduction}

One of the key elements of the system transition in post-communist countries is the need for democratization, decentralization and implementation of best practices of the European governance also on regional and local level. That is why since gaining independence in 1991 these reforms have featured prominently in agenda of political and economic transformation in Ukraine. Unlike Poland and some other Central and Eastern European countries in the 
region, today members of the EU, Ukraine's transition from heavily centralized to decentralized system took much longer. In fact this is still an ongoing process. Some basic attempts were done already in the 1990's (articles 140146 of the Ukrainian Constitution adopted in 1996 acknowledged the general principles of local self-government separated from the state government) but only during recent years, strengthened by the so called Euromaidan Revolution in 2014, Ukraine has adopted proper laws and began to implement a series of more radical changes in the field. The attempts of public administration transformation that have been concluded since gaining the independence in Ukraine have been studied widely in the literature (Kuczabski, Zastavetska, Zastavetskyy, 2017, pp. 87-91; Radyszewska, 2017, pp. 195-199; Udovychenko, Melnychuk, Gnatiuk, Ostapenko, 2017, pp. 23-26; European Committee of the Regions, 2017).

Decentralization efforts are typically politically motivated, that is for sure also true in case of Ukraine where the pace of reform accelerated following Ukraine's involvement with the Eastern Partnership process and "express commitment to the goal of Ukraine's eventual accession to the EU" (European Committee of the Regions, 2017, $p$. 11). Despite political importance, these reforms have profound impacts on economies by influencing, among other things, governance in the public sector. This includes public services as in the theory, decentralization is argued to improve governance in public service provision in at least three ways: by improving the efficiency of resource allocation; by promoting accountability and reducing corruption within government; and by improving cost recovery (Azfar, Kähkönen, Lanyi, Meagher, Rutherford, 1999, pp. 3-4).

The subsidiarity principle also argues that "the efficient provision of public goods and services requires that the government satisfy citizens' needs and preferences as much as possible" (Kimr, 2008, p. 11). The reconstruction of the public administration system is usually accompanied by the changes in territorial division as it forms "as structure by means of which specific spatial governance in the implementation of public tasks is obtained" (Kuczabski, Zastavetska, Zastavetskyy, 2017, p. 87). Though it can be said that the recently adopted acts constitute legal basis not only for the distribution of powers between the authorities at various levels of administrative and territorial system based on the European standards such as principles of subsidiarity and decentralization, but they should also allow to improve the quality and efficiency of public services. In this sense strengthening public services should be supported by the real decentralization process.

The aim of the article is to present the recent attempts for decentralization and local reforms and their impacts in Ukraine in order to indicate achievements and the possibilities of strengthening public services through the implementation of self-government and public governance standards developed by the Council of Europe and the European Union. The research was based on the review of current legal acts, action documents and scientific literature connected with decentralization and self-government.

\section{Public services in regional and local perspective - the basic legal framework of the Council of Eurpope}

Public services can be determined as "services or activities, recognised as public in the sense that the State is seen as ultimately responsible for the provision of them (but which) are nevertheless not provided by the State itself but by institutions which are intermediate between the market and the State. These institutions are, on the one hand, too independent of the State to be regarded as part of the State, but are, on the other hand, too closely and distinctly associated with the goals, activities, and responsibilities of the State" (Freedland, 1998, p. 3). The term public services "refers to the fact that a service is offered to the general public, it sometimes highlights that a service has been assigned a specific role in the public interest, and it sometimes refers to the ownership or status of the entity 
providing the service" (CEEP..., 2010, p. 10). In a wide approach public services can include (CEEP..., 2010, p. 14): telecommunications, postal services, production of electricity, gas and electric networks (transport-distribution), railway transport of passengers, freight rail transport, regional and local transport of passengers, air transport, inland water transport, maritime transport, water, waste water, heating, broadcasting, hospital health services, ambulatory health services, primary and secondary education, higher education, vocational training, compulsory social protection, complementary social protection, social housing, childcare services, care of the disabled, elderly care, administrative, financial and cultural services, etc.

The European Charter of Local Self-Government accepted in 1985 by the Congress of Local and Regional Authorities of the Council of Europe indicates the importance of communities as a basis for the exercise of democracy (the preamble states that "the local authorities are one of the main foundations of any democratic regime"). Its regulation also stipulate that "local self-government denotes the right and the ability of local authorities, within the limits of the law, to regulate and manage a substantial share of public affairs under their own responsibility and in the interests of the local population" (Council of Europe, 2016, p. 12). It is emphasized that The Charter is also "a source of inspiration when countries decide to establish or reform their regional authorities" (Council of Europe, 2017, p. 6).

The Council of Europe underlines the importance of public services in strengthening territorial cohesion. The principle of territorial cohesion is defined as "the principle of equity among citizens, regardless of where they live: the objective of territorial cohesion is to provide citizens with equitable conditions of access to public services and ensure optimum conditions in terms of competitiveness, balanced, sustainable development and the improvement of the quality of life throughout the country, with due regard in particular for the diversity of geographical and demographic situations" (Council of Europe, 2017, p. 13). The European Charter of Local Self-Government contains some references to public services. From the perspective of good governance and the performance of public tasks at regional level very important is "the principles of good administration and good quality of public services" (Council of Europe, 2017, p. 24). According to Additional Protocol to the European Charter of Local Self-Government on the right to participate in the affairs of a local authority from 2009, the measures for the exercise of the right to participate shall include "mechanisms and procedures for dealing with and responding to complaints and suggestions regarding the functioning of local authorities and local public services" (Council of Europe, 2016, p. 28).

\section{Decentralization in Ukraine as a way to public services improvement}

Considering the aim connected with strengthening the public services provision on local level it can be said that the most recent reforms concerning decentralization and self-government started with the adoption of (just to name some) the Concept of the Reform of Local Self-Government and Territorial Organization of Government in Ukraine by the Order of the Cabinet of Ministers on $1^{\text {st }}$ of April, 2014 (No. 33, Official Journal of Ukraine, 2014, No. 30, art. 831) and the Law "On the Cooperation of Territorial Communities" (No. 1508-VII as of June 17 ${ }^{\text {th }}, 2014$ ). Ukrainian Parliament elected already after Euromaidan protests adopted also the Law "On Voluntary Association of Territorial Communities" (No. 157-VIII as of February $\left.5^{\text {th }}, 2015\right)$ and others, like changes to the Budget and Tax Codes allowing some financial decentralization, etc. This process has allowed forming, in accordance with the provisions of the European Charter of Local Self-Government (ratified by Ukraine already in 1997), a significant and effective local self-government at the basic level - united territorial communities.

Territorial community in Ukraine is the residents united by permanent residence within the village, city, which are independent administrative and territorial units, or voluntary association of residents of several villages with 
a single administrative centre (Verkhovna Rada of Ukraine, 2015). Several communities form the district, and the provinces are regions of Ukraine. According to the Minister for Regional Development, Building and Housing of Ukraine - 803 united territorial communities have been created in Ukraine as of August, 2018 and 98 of which are awaiting decisions of the Central Election Commission on the appointment of the first elections (Segodnya, 2018). The composition of these united territorial communities includes 3,372 former local councils. At the legislative level, the institute of the village headman in the united territorial communities, which represents the interests of the villagers in the council of the community, the executive committee and may provide administrative services on the territory of the high council, is also introduced. It should be also noted that in Ukraine there are 15 districts, within which all the communities have united, there is a duplication of functions of the structural units - the district is a united community. In the other territories where the integration of communities occurred, local governments at the district level continue to exercise their powers in the spheres of education, medicine, culture and social protection. That is, today there is a problem of duplication of functions at the district level between local governments, united territorial communities and local district levels (Serebryanskaya, 2018).

Theoretical and empirical evidence show that the main problem when conducting decentralization reforms is to find balance between decentralization and centralization adequately to the real socio-economic and political conditions of a particular country. Taking this into account, one of the main goals when designing the decentralization pattern is to improve the quality of public services. The decision on the transfer of authority to a lower level implies that there is a subject that, in the case of the transfer of these powers, will ensure their better execution than at the state level (Voitovich, Vorona, 2018, p. 42). In order to form a base for efficient public services on local level the important trends in the development of local self-government in Europe can be mentioned: the consolidation of administrative-territorial units, reduction of a number of local authorities, creation of different regional forms of management (Kregul, Batrymenko, 2016, p. 20).

The main idea of decentralization of power in Ukraine is the approximation of management services to the consumer, i.e. to the population. Adoption of laws to extend the powers of local self-government bodies and optimize the provision of administrative services allowed delegating to local government bodies the appropriate level of authority to provide basic administrative services: registration of residence, issuance of passport documents, state registration of legal and natural persons, entrepreneurs, associations of citizens, registration of acts of civil state, rights, land issues, etc. (Voitovich, Vorona, 2018, p. 83). Financial decentralization creates further conditions for the socio-economic development of territories, including area of public services. State financial support of the united territorial communities contributes to the formation of social infrastructure and the creation of new jobs. United communities received powers and resources that have cities of regional importance, in particular, the transfer of $60 \%$ of personal income tax to local budgets of joint territorial communities. In addition, revenues from taxes are completely in place: single, for the profits of enterprises and financial institutions of communal property and property tax (real estate, land, transport). The growth rate of local taxes and fees in the united territorial communities is $29.4 \%$ (for 11 months of 2017 ), which is more than the average in Ukraine by $24.9 \%$. In particular, the payment for the land increased by $20 \%$, income tax on real estate - more than $70 \%$. However, as the analysis shows, $92 \%$ of registered rural communities constitute the population of retirement age, and half of their total number have a budget subsidy level of about $70 \%$. Therefore, it is impossible to expect rapid positive changes in the social sphere of rural areas under such conditions in the near future (Voitovich, Vorona, 2018, p. 129). 
Assessing the positive aspects of the implementation of management reforms that began after 2014 in Ukraine, it is advisable to note that the reforms are carried out precisely in the areas of health care reform, education, public administration, etc. However, according to the National Reform Council, when polling 1,000 respondents at the end of 2017, the population thus evaluated the implementation of reforms: in the field of education, only $44 \%$ of respondents indicated positive changes in health care $-33 \%$, in the fight against corruption $-24 \%$. Moreover, a significant part (about 2/3) of the respondents have a rough idea of the purpose and content of the reforms (Voitovich, Vorona, 2018, pp. 139-140).

\section{Public services development in Ukraine - some selected examples}

In Ukraine, the model of provision of services is applied through the corresponding centres of administrative services established by the state and municipal authorities. The legal framework and forms of activity of centres for the provision of administrative services are determined by the Law of Ukraine "On Administrative Services" (adopted already on $6^{\text {th }}$ August, 2012, published in Official Journal 2013, No. 32, art. 409). The list of services that can be provided in the field is constantly expanding. At present, there are about 1,500 administrative services in Ukraine. Residents of united communities expect convenient and high-quality administrative services from local authorities. That is why it is important that each united community quickly decide how mobile and affordable it is to provide these services to residents. All services of the authorities should be as close as possible to people and the creation of such a structure as the Centre for the Provision of Administrative Services (CPAS) that are considered to solve this issue. After the adoption of the Law "On Administrative Services", the creation of such integrated offices became mandatory for large cities and districts. CPAS in big cities provide services for about 55 hours per week (Ukraine Office, 2018). The quality of work of the CPAS determines the level of citizens' trust in the government, directly depends on how the state performs its functions, where the provision of administrative services occupies one of the key positions (Voitovich, Vorona, 2018, p. 82).

Out of 723 units, 454 administrative service centres operated under district state administrations. However, according to the provisions of the Local Government Reform Concept (adopted by the Cabinet of Ministers Order No. 333 of $1^{\text {st }}$ of April, 2017), the district level of the administrative-territorial structure will be reformed organization of associations. It is obvious that in the united communities modern CPAS should be also created. When talking about quality of service and modern standards in administration, special attention should be paid to the Ukrainian electronic service iGov, which was developed by a volunteer team as part of the fight against corruption in Ukraine and the improvement of business processes in government. This electronic portal contains services that state and municipal authorities provide to citizens and businesses (iGov. Portal..., 2018). The above described improvements concerning administrative services can be illustrated with some territorial examples. At present, the leader in Ukraine in the number of concluded inter-municipal cooperation agreements is Poltava region. As in total of 180 cooperations in the country, 57 of which are registered in this region. More specifically, 45 of them are related to the implementation of joint projects, six contracts concern the joint financing of municipal property organizations, four - delegation of authority, and two more - creation of joint utility companies.

The conclusions from recently concluded inter-municipal cooperation contracts showed that there are people living in Poltava region who are ready to unite in order to solve typical common problems. In 2015, this area of work was the impetus for the unification of local councils in the united territorial communities. The present united communities can start the necessary projects not only in cooperation with their neighbors, but also independently. 
Thus, in the Semenovskaya united territorial community, the "House of Protected Senility" has been created for the residents. Such communal institution for lonely people is planned also to be created in Omelnytsky united territorial community. Financial receipts in the united territorial communities of the Poltava region grew from two to five times in comparison with the financing of these communities before the unification. In 2017, 27 projects of international technical assistance were implemented in Poltava region (in 2016 - 17, in 2015 - 14 and in 2014 - only 9) and six projects of international financial assistance. In partnership with international organizations and foundations, such programs as the Ukrainian-Canadian project "Partnership for urban development "PROMIS", the UNDP/EU project "Local Community-Oriented Development", the Swiss-Ukrainian project DESPRO "Support for Decentralization in Ukraine", the GIZ project "Governance Reform in the East of Ukraine II" and the European Union's large-scale program "U-LEAD with Europe" are also implemented here (Poltavshchyna, 2018).

\section{Conclusions}

The researched issue remains important and current as despite some evidenced improvements Ukraine still occupies low positions in global competitiveness rankings related to public governance. For example according to The Global Competitiveness Report 2017-2018, Ukraine holds general rank 81st out of 137 countries (according to 2016-2017: $85^{\text {th }}$ ), and $65^{\text {th }}$ (previously $99^{\text {th }}$ ) regarding transparency of government policymaking included in the pillar connected with institutions (World Economic Forum, 2018, pp. 296-297; Radyszewska, 2017, p. 198). As it was presented in the paper, Ukraine has already adopted the necessary laws that, to one degree or another, regulate public relations associated with decentralization and self-government. They had also impact on public service provision system but with different strength when taking into account the type of service or a region. Moreover, comparing the Ukrainian local authorities' permissions and activities with the experience of other post-communist counties that conducted the decentralization reforms and are usually considered relevant examples for Ukraine (such Poland) it is clear that these laws are not sufficient (Voitovich, Vorona, 2018, pp. 42-43). The studied reforms are an ongoing process, so the evidence was given on the selected examples that is administrative services and supporting public services in Poltava region but as it was revealed there are still some problems to be resolved.

Therefore it must be said that reforms connected with decentralization and self-government empowerment allowing strengthening the public services provided on local level are not finished yet in Ukraine. It is still necessary to develop effective by-laws to regulate the procedures for the application and implementation of laws on local self-government, as well as to expand the list of administrative services provided to residents of united territorial communities. Besides these legal changes, in order to improve the functioning of the system of providing administrative services in the united territorial communities of Ukraine, some practical steps must be taken, such as:

a) to provide state support for expanding the network of united territorial communities in order to cover the entire territory of Ukraine;

b) to ensure organizational unity of the front office and back office of the centres providing administrative services of the united territorial communities;

c) to familiarize the use of the electronic portal of state services iGov, what will allow to effectively fight against corruption and improve the public services provision system at any territorial level;

d) to develop and implement efficient educational programs for public administration employees on the effective provision of administrative services. 


\section{References}

Azfar, O., Kähkönen, S., Lanyi, A., Meagher, P, Rutherford, D. (1999). Decentralization, Governance and Public Finance Services. The Impact of Institutional Arrangements. A Review of the Literature. IRIS Centre, University of Maryland, College Park. Retrieved from: https://pdfs.semanticscholar.org/c939/64bf93ed332e1204026154ee1cf93035cb7e.pdf.

CEEP - Centre Européen des Entreprises à Participation Publique (2010). Public Services in the European Union \& the 27 Member States: Statistics, Organisation and Regulations. Brussels: Mapping of the Public Services.

Council of Europe (2017). Reference Framework for Regional Democracy. Congress of the Local and Regional Authorities of the Council of Europe.

Council of Europe (2016). European Charter of Local Self-Government. Congress of the Local and Regional Authorities of the Council of Europe.

European Committee of the Regions (2017). Regional Development in Ukraine: Priority Actions in Terms of Decentralization. Retrieved from: https://cor.europa.eu/en/engage/studies /Documents/Regional-Development-Ukraine.pdf.

Freedland, M. (1998). Law, Public Services and Citizenship - New Domains, New Regimes? In: M. Freedland, S. Sciarra (eds.), Public Services and Citizenship in European Law: Public and Labour Law Perspectives (pp. 1-34). Oxford: Oxford University Press.

Government Portal (2018). The Decentralization Reform. Retrieved from: https://www.kmu.gov.ua/ua/diyalnist/reformi/ reforma-decentralizaciyi.

iGov. Portal of public services (2018). Retrieved from: https://igov.org.ua.

Kimr, A. (2008). Decentralization and the Provision of Public Services: Framework and Implementation. Policy Research Working Paper 4503, The World Bank, 1-25.

Kregul, Y., Bartmenko, V. (2016). Reform of Local Self-Government in Ukraine. Foreign Trade: Economics, Finance, Law, 1 (84), $17-27$.

Kuczabski, A., Zastavetska, L., Zastavetskyy, T. (2017). The Reform of Administrative Division in Ukraine: Problems of Territorial Communities' Formation in the Polish-Ukrainian Borderland. Journal of Geography, Politics and Society, 7 (2), 87-97.

Poltavshchyna, (2018). Supporters of Decentralization from the East of Ukraine Adopt the Best Practices of Community Cooperation in Poltava Region. Retrieved from: https://poltava.to/project/3720.

Radyszewska, O. (2017). Public Administration Reform in Ukraine in the Face of European Integration. Studia luridica, 71, $195-206$.

Segodnya (2018). White Spots on the Map of Ukraine: Not a Single Territorial Community Was Created in 116 Districts. Retrieved from: https://www.segodnya.ua/ukraine/belye-pyatna-na-karte-ukrainy-v-116-rayonah-ne-sozdano-ni-odnoy-territorialnoyobshchiny-1162774.html (29.09.2018).

Serebryanskaya, D. (2018). Assessment of the Implementation of the Objectives of the Concept of Reforming Local Government and the Territorial Organization of Power in Ukraine. Retrieved from: http://ngoipr.org.ua/news/otsinka-vykonannya-zavdan-kontseptsiyireformuvannya-mistsevogo-samovryaduvannya-ta-terytorialnoyi-organizatsiyi-vlady-v-ukrayini.

Udovychenko, V., Melnychuk, A., Gnatiuk, O., Ostapenko, P. (2017). Decentralization Reform in Ukraine: Assessment of the Chosen Transformation Model. European Spatial Research and Policy, 24 (1), 23-40.

Ukraine Office (2018). On the Way to Building the Service State. Retrieved from: https://ukraineoffice.blogactiv.eu/2018/02/20/ on-the-way-to-building-a-service-state.

World Economic Forum (2018). The Global Competitiveness Report 2017-2018. Retrieved from: www3.weforum.rg/docs/GCR20172018/05FullReport/TheGlobal CompetitivenessReport2017-2018.pdf.

Verkhovna Rada of Ukraine (2015). Resolution "On preliminary approval of the draft law on amending the Constitution of Ukraine regarding the decentralization of power". 31.08.2015. No. 656-VIII. Retrieved from: http://zakon3.rada.gov.ua/laws/show/656-19 (12.10.2018).

Voitovich, R.V., Vorona, P.V. (2018). Scientific and Practical Support for the Decentralization of the Provision of Services in the United Territorial Communities. Materials of Scientific and Practical Conference of $18^{\text {th }}$ of April, 2018. Kyiv: Ukrainian State Employment Service Training Institute (USESTI).

Cite this anticle aS: Ignasiak-Szulc, A., Kucherenko, S., Jaźwiński, I., Riznyk, V. (2018). Development of Public Services through the Implementation of European Self-Government Standards in Ukraine. European Journal of Service Management, 4 (28/1), 143-149. DOI: 10.18276/ejsm.2018.28/1-18. 